\title{
ON CERTAIN MEAN VALUE THEOREMS
}

\author{
TH. M. RASSIAS AND Y. H. KIM
}

Abstract. In this paper we have obtained a symmetric integral mean $M\left(a, b ; p\left(r_{n, k}\right), q\right)$ involving functions which a generalization of the arithmetic-geometric mean of Gauss. We have also proved some characterization of the symmetric mean values for the twice continuously differentiable function $p$.

Mathematics subject classification (2000): 26E60, 34A34, 39B22.

Key words and phrases: Arithmetic-geometric mean of Gauss, symmetric mean, monotonic function, partial derivative, differential equation.

\section{REFERENCES}

[1] S. Abramovich And J. PeČArić, New properties of some mean values, J. Math. Anal. Appl. 232 (1999), 376-383.

[2] H. Alzer, On Stolarsky's mean value family, Int. J. Math. Educat. Sci. Tech. 20 (1) (1987), 186-189.

[3] P.S. Bullen, D.S. Mitrinović And P.M. VAsić, Mean and Their Inequalities, Reidel, Dordecht, 1988.

[4] P.S. CARlson, The logarithmic mean, Amer. Math. Monthly 79 (1972), 615-618.

5] L. Galvani, Dei limiti a sui tendono alcune media, Bol. Un. Mat. Ital. 6 (1927), 173-179.

[6] D.S. Mitrinović, J.E. PEČARIĆ AND A.M. FinK, Classical and new Inequalities in Analysis, Kluwer Academic Publishers, Dordrecht, Boston, London, 1993.

[7] H. HARUKI, New characterizations of the arithmetic-geometric mean of Gauss and other well-known values, Publ. Math. Debrecen 38 (1991), 323-332.

[8] H. HARUKI AND T.M. RASSIAS, New characterizations of some mean-values, Jour. of Mathematical Analysis and Applications 202 (1996), 333-348.

[9] H. HARUKI AND TH.M. RASSIAS, A new analogue of Gauss' functional equation, Internat. Journal of Math. and Math. Sciences 18 (1995), 749-756.

[10] P. Kahlig AND J. MatKowsKi, On the composition of homogeneous quasi-arithmetic means, Jour. of Mathematical Analysis and Applications 216 (1997), 69-85.

[11] Y.H. KIM, New characterizations of well-known mean-values, Far East J. Math. Sci. 6(6) (1998), 939-947.

[12] Y.H. Kim AND Th.M. RASsias, Properties of some mean values and functional equations, Panamer. Math. J. 12(1) (2002), 65-74.

[13] G. PÓLYA AND G. SZEGÖ, Isoperimetric Inequalities in Mathematical Physics, Princeton University Press, 1951.

[14] F. QI, Generalized weighted mean values with two parameters, Proc. Royal Soc. London A. 454 (1998), 2723-2732.

[15] P.K. SAHOO AND T. RIEDEL, Mean Value Theorems and Functional Equations, World Scientific Publ. Co., Singapore, New Jersey, London, 1998.

[16] K.B. Stolarsky, Generalizations of the logarithmic mean, Math. Mag. 48 (1975), 87-92.

[17] GH. TOADER, Some mean values related to the arithmetic-geometric mean, Jour. of Mathematical Analysis and Applications 218 (1998), 358-368.

[18] GH. TOADER AND T.M. RASSIAS, New properties of some mean values, Jour. of Mathematical Analysis and Applications 232 (1999), 376-383. 
[19] S. TOAder, Th.M. Rassias And G. TOAdER, A Gauss type functional equation, Int. J. Math. Math. Sci. 25(9) (2001), 565-569. 